This is the peer reviewed version of the following article: Mambeya MM, Baker $\mathrm{F}$, Momboua BR, et al. The emergence of a commercial trade in pangolins from Gabon. Afr J Ecol. 2018;56:601-609, which has been published in final form at https://doi.org/10.1111/aje.12507. This article may be used for non-commercial purposes in accordance With Wiley Terms and Conditions for self-archiving. 


\section{The emergence of a commercial trade in pangolins from Gabon}

2

\section{Running title: Emerging trade in pangolins in Gabon}

Meine Marie Mambeya*1, Francesca Baker ${ }^{2}$, Brice Roxan Momboua ${ }^{3,4}$, Aurélie Flore Koumba Pambo ${ }^{4,5}$, Martin Hega ${ }^{6}$, V. Joseph Okouyi Okouyi ${ }^{4,7}$, Martial Onanga ${ }^{4}$, Daniel W.S. Challender ${ }^{8,9}$, Daniel J. Ingram ${ }^{8,10}$, Wang Hongyan ${ }^{1}$, \& Katharine Abernethy ${ }^{7,11}$

${ }^{1}$ North East Agricultural University of Harbin, Harbin, China

${ }^{2}$ Institute for Conservation Science, Imperial College London, UK

${ }^{3}$ Département de Biologie, Faculté des Sciences, University des Sciences et Techniques de Masuku, BP 554, Franceville, Gabon

${ }^{4}$ Agence Nationale des Parcs Nationaux, BP 20379, Libreville, Gabon

${ }^{5}$ Centre National de Recherches Scientifiques et Technologies, BP 842, Libreville, Gabon

${ }^{6}$ Wildife Conservation Society Gabon, Batterie IV, Libreville, Gabon.

${ }^{7}$ Institut de Recherche en Ecologie Tropicale, BP 15539, Libreville, Gabon

${ }^{8}$ IUCN SSC Pangolin Specialist Group, \% Zoological Society of London, Regents Park, London NW1 4RY, UK

${ }^{9}$ Durrell Institute of Conservation \& Ecology, School of Anthropology and Conservation, University of Kent, Canterbury, Kent, CT2 7NR, UK

${ }^{10}$ School of Life Sciences, University of Sussex, Brighton, BN1 9QG, UK

${ }^{11}$ African Forest Ecology Group, Biological and Environmental Sciences, University of Stirling, Stirling FK9 4LA, UK.

Meine Marie Mambeya (*submitted posthumously)

Francesca Baker :francesca.baker@live.co.uk

Brice Roxan MOMBOUA: bekouya@outlook.fr

Aurelie Flore Koumba Pambo scienceparcsgabon@gmail.com

Martin Hega: mhega@wcs.org

V.Joseph Okouyi Okouyi: okouyi joseph@yahoo.fr

Martial Onanga: onangamartial@yahoo.fr

Dan Challender: dan_pangolin@hotmail.co.uk

Daniel Ingram: D.Ingram@sussex.ac.uk

Wang Hongyan: why220@126.com

Katharine Abernethy: k.a.abernethy@stir.ac.uk

\section{Corresponding author: k.a.abernethy@stir.ac.uk}




\section{Acknowledgements}

42 To our immense sadness, the primary author of this work, Meine Marie Mambeya,

43 passed away in January 2017 after a long struggle with cancer. Her dedication to her

44 work, to ecological research and to the protection of African pangolins was an

45 inspiration to all of us and a model for the new generation of African conservation

46 scientists. We thank her enormously for her contribution and hope that the

47 publication of her work will be an everlasting tribute to her. We thank CENAREST for

48 permission for research in Gabon and the Institut de Recherche en Ecologie

49 Tropicale (IRET) and the Agence Nationale des Parcs Nationaux (ANPN), Gabon for

50 support for the field work. In particular we thank Conservators Daniel Nzame and

51 Rostand Ab'aa; Professors Lee White, Jacques Mavoungou and EJ Milner-Gulland;

52 Drs Kathryn Jeffery and Vincent Mejibe and M. Christian Mbina for general support

53 and advice. Data collection costs and resources were supported by IRET (VJOO);

54 ANPN (MMM, FKP, MO, BRM); the IUCN SSC Pangolin Specialist Group (FB, MMM,

55 BRM); University of Masuku (BRM) and the University of Stirling (KA). Analysis and

56 writing costs in addition to the support of the authors' institutions were provided by

57 the IUCN SSC Pangolin Specialist Group and the Gabonese Republic (Student grants

58 service).

59

60 


\section{Abstract}

62 Recent seizures of illegally-held wildlife indicate a mounting global trade in pangolins

63 involving all eight species. Seizures of illegally-traded African pangolins are

64 increasing as wild populations of Asian species decline. We investigated trade in

65 pangolins and law enforcement efforts in Gabon; a country likely to have intact wild

66 populations of three of the four species of African pangolin. We compared village

67 sales and trade chains between 2002-3 and 2014. Hunters reported pangolins to be

68 the most frequently requested species in 2014 and the value of pangolins had

69 increased at every point along their trade chain. In Libreville, giant pangolin prices

70 increased $211 \%$ and arboreal pangolin prices $73 \%$ whilst inflation rose only $4.6 \%$

71 over the same period. We documented a low rate of interception of illegally-traded

72 pangolins despite increased law enforcement. Surveys of potential export routes

73 detected exports across forest borders, in conjunction with ivory, but not through

74 public transport routes. We conclude that whilst there is clear potential and

75 likelihood that a wild pangolin export trade is emerging from Gabon, traditional

76 bushmeat trade chains may not be the primary supply route. We recommend

77 adjusting conservation policies and actions to impede further development of illegal

78 trade within and from Gabon.

79

80 Keywords: pangolins, illegal wildlife trade, Gabon, hunting, bushmeat, 
Main text

\section{Introduction}

Although trade in wildlife products is an ancient human endeavor, wild populations of many species are currently suffering declines as demand in global markets drives unsustainable exploitation. Drastic population declines attributed primarily to commercial harvests are reported in diverse terrestrial and marine taxa and IUCN's (International Union for Conservation of Nature) The Red List of Threatened Species $^{\mathrm{TM}}$ now lists 8,613 species as threatened by overexploitation worldwide (IUCN, 2014; Ripple et al., 2016). The majority of impacts on terrestrial species are felt in tropical regions (Dirzo et al., 2014) and of these, mammals suffer more than any other species group (Ripple et al., 2016).

Commercial exploitation has been the key factor in the rapid decline of wild populations of Asian pangolin species in recent decades (Challender et al., 2015; Challender, 2011). Unsurprisingly, this has led to an overall rise in international trade as well as trafficking of African pangolins, primarily their scales, to Asia (Challender \& Waterman, 2017; Challender and Hywood, 2012; Newman et al., 2014; Nijman et al., 2016). Increasing global economic and trade links but particularly new links between African nations and East Asia have possibly facilitated this trade (Challender et al., 2016; Wang and Bio-Tchané, 2008). The vast majority of international demand for pangolins comes from Asia, and in particular China and Vietnam (Challender et al., 2015; Nijman et al., 2016). However, exact countries of origin of traded African pangolins, which are found in many range states, are unattributed for the majority of seizures made (though see Challender \& Waterman, 2017). Over the past decade China has developed increasing economic ties with Africa, in particular through 
direct investment (Abernethy et al., 2016) and Chinese companies now have permanent bases, resident workers and administrative networks in countries across the continent (Wang and Bio-Tchané, 2008; Putzel et al., 2011).

Based on available evidence, which is likely to be a partial picture, international

109 seizures of illegally traded products from African pangolins are increasing. Four kg of

110 African pangolin products were seized in 2008, $312 \mathrm{~kg}$ in 2012, 4 tonnes of scales

111 were seized in Cameroon in 2016 and another 5.4 tonnes were seized in early 2017

112 (LAGA, 2017), this last representing 10,000 - 20,000 pangolins (see Challender \&

113 Waterman, 2017 for a comprehensive overview of global seizures). This is ostensibly

114 an exponential rise which, despite some targeted international law enforcement

115 efforts, may be signalling a mushrooming illegal trade, rather than dramatic

116 improvements in the detection of trafficking.

117 Gabon is home to three of the four African species of pangolin, the fossorial giant

118 pangolin (Smutsia gigantea, Illiger 1815); and the arboreal white-bellied pangolin

119 (Phataginus tricuspis, Rafinesque 1821) and black- bellied pangolin (Phataginus

120 tetradactyla, L. 1766) (Kingdon and Hoffman, 2013). Giant pangolins have been

121 integrally protected nationally since 1987 (Republique Gabonaise, décret $n^{\circ}$

122 189/PR/MEFCR), but both Phataginus (arboreal) species can be legally hunted

123 locally, although hunting methods, catch sizes, seasons and trade are regulated.

124 However, despite regulation, a nationwide six-year survey of sixteen bushmeat

125 markets (2000-2006) recorded arboreal pangolins in all markets in all months,

126 accounting for $10 \%$ of all animals traded annually (Abernethy and Ndong Obiang,

127 2010). In two year-long village hunting studies during the same period white-bellied

128 pangolins were caught by village hunters every month and formed approximately $6 \%$ 
129 of all animals caught annually (Coad, 2007; Van Vliet, 2008). There is no census data

130 for any pangolin species in the wild in Gabon.

131 In the face of the global rise in illegal wildlife trade in recent years and in particular

132 the threat to African mammals (London Declaration, 2014; Kasane Statement, 2015),

133 anti-poaching efforts have been increased in Gabon and in particular for species

134 likely to be at highest risk. Sniffer dogs trained for the detection of ivory, ape and

135 pangolin products have been working at roadblocks, railway stations, airports and

136 seaports since 2013, in an effort to intercept wildlife being traded illegally.

137 In this first evaluation of trade risk to Gabonese pangolins, our specific objectives

138 were to:

139 a) describe the current trade of pangolins in rural areas and rural-to-urban

$140 \quad$ scenarios;

141 b) evaluate the extent of change over the past decade in the species and

142 relative value of species involved this trade, with particular attention to

143 change in the value of pangolins relative to other species;

144 c) assess the extent to which rural hunting communities may be the source of

145 pangolins for export or whether the species are potentially sourced outwith

146 the traditional bushmeat trade;

147 d) evaluate the trade routes for pangolins within and from Gabon,

148 e) evaluate the current control of trade; and using the data we acquire for

149 points a-e;

150 f) propose actions to more effectively combat any emerging high-value trade in 151 these species outside the traditional subsistence economy. 
152 To address these objectives, we collected data in traditional subsistence villages on

153 hunter sales; trade prices at the 'forestgate'; in the provincial town markets supplied

154 and in the capital; and law enforcement efforts in 2014. We compared our results to

155 existing data collected variously between 2000 and 2006.

\section{Methods}

157 Village hunting and 'forestgate' trade in 2014

158 Pangolin offtake and sales were assessed in local communities living in rural

159 subsistence economies (which include hunting for meat and income). The hunted

160 areas were not protected areas and arboreal pangolins could be legally hunted

161 under traditional customary rights. We assessed the numbers of pangolins traded in

1622014 from villages in the Ogooué-Ivindo and the Nyanga provinces in Gabon both to

163 local clients and, via roadside sales to traders, into larger markets. The two key

164 provinces were chosen for the following reasons: a) comparative data were available

165 from the previous decade (Okouyi Okouyi, 2006; Abernethy and Ndong Obiang,

166 2010); b) both provinces have relatively recently seen the arrival of populations of

167 migrant Asian workers, specifically in the construction, agro-industrial and logging

168 industries (Oxford Business Group, 2015); and (c) these areas broadly represent the

169 two major catchment habitats of completely forested (Ogooué Ivindo) and

170 savannah/forest mosaic (Nyanga) found in Gabon. Surveys of village hunters were

171 made in the dry season during a 43-day study period in the Ogooué-Ivindo (June-July

172 2014), and a 10-day period in the Nyanga (early August 2014). During these studies,

17324 villages were surveyed (Figure 1). Surveys comprised data collection on village

174 characteristics (questionnaires filled by the village chief or elder hunter) and semi-

175 structured interviews with hunters on hunting activity, client requests, sales and 
revenues from the past month. Examples of the questionnaires are given in

177 Supplementary Materials and can also be found in Baker, (2014) and Mambeya,

178 (2015).

179 A total of 138 villagers participated in the research. Of these initial survey

180 respondents, 69 villagers in ten villages in the Ogooué Ivindo and 34 villagers in ten

181 villages in the Nyanga (total 103) reported hunting actively and were further

182 interviewed. Villages ranged from 64-800 people (median 200) with between one

183 and fifteen hunters (median 4). All interviewed hunters were men, aged between 16

184 and 70 years, with the majority in the $31-50$ year-old age class (57. 3\%). Over $90 \%$ of

185 interviewees were native to the village (born there or living with family born there)

186 and gave subsistence as their primary reason for hunting. Culture, protection of

187 plantations and supplementary income were also reasons (9.3\%), but no hunter

188 reported even legitimate local commercial trade as their primary motivation for

189 hunting. Hunters used guns $(47.6 \%)$ or snares $(28.1 \%)$ or both $(24.3 \%)$ and all

190 hunters reported hunting within one day's walk from their village without using

191 camps. Comparison with available literature shows that these village hunting

192 communities conform to previously established profiles for subsistence communities

193 in Gabon in terms of hunter ages, hunter numbers per village, hunting catchment

194 distances from the village (one day's walk or max $10 \mathrm{~km}$ ), species caught,

195 percentages traded and price equivalency between species (Coad, 2007; Foerster et

196 al., 2011; Okouyi Okouyi, 2006; Starkey, 2004; Van Vliet, 2008). 
Detailed studies of village hunting had been carried out in 2002-2003 in the OgoouéIvindo (Okouyi Okouyi, 2006) which allowed us to analyze changes over time in local

201 farmgate, or rather 'forestgate', sale prices for the Ogooué Ivindo. Data on date, 202 time and location of sale, species sold, carcass state (whole or butchered parts, fresh 203 or smoked) and price obtained were collected over fourteen months in 2002-2003 in 204 six villages around Makokou (detailed methods in Okouyi Okouyi, 2006) and 205 Makokou market itself. Comprehensive surveys of sixteen town and village markets 206 in Gabon from 2000-2006 showed that prices did not fluctuate significantly between 207 seasons of a year (Abernethy \& Ndong Obiang, 2010), however hunter offtake rates 208 could alter between seasons (Coad, 2007). We limited the hunter sales data analysed 209 from 2002-2003 to the months of May - August (dry season) to limit any potential 210 bias of offtake volume or composition on hunter trade decisions between the 211 compared study periods.

213 Change in relative value of species, within and along the traditional trade chain

214 To investigate change over time in the relative value of traded bushmeats we looked 215 specifically at the Ogooué-Ivindo market chain, from which we had comparable data 216 from 2002-2003 and 2014. Market surveys in Makokou and surrounding villages 217 were carried out for all sales in six markets on one day per week during 2002-2003 218 and one to three days per location during three months May-July in 2014. Data from 219 Libreville Mont Bouët market, also collected from 2002-2003 allowed analysis of the 220 evolution of relative value of species over the past twelve years for these locations.

221 We included the five most common other species groups recorded in our national 222 surveys in both 2002-2003 and 2014 (blue duiker (Philantomba monticola, Thunberg 
223

224 (Cephalophus spp.), red river hog (Potamochoerus porcus, L. 1758) and guenons

225 (Cercopithecus spp.) and both pangolin types (Table 1). Prices were standardized to

226 per kg prices for comparisons between species, using mean weights of hunted

227 animals recorded directly in villages in Gabon (Coad, 2007; Abernethy \& Ndong

228 Obiang, 2010). For comparison of the price of the same species over space and time,

229 we used sales of whole animals only to reduce inherent noise from standardizing

230 weights of butchered animals. We did not use a purchasing power parity or

231 Consumer Price Index (CPI) correction between years, as inferences were drawn

232 from the relative rank value of traded species across space, rather than from their

233 absolute values. However, between the start of 2002 and the end of 2014, Gabon's

234 inflation (percentage change in CPI) was approximately 4.6\% (World Bank, 2017),

235 thus a rise of up to $5 \%$ in absolute value of products, may not indicate any real

236 change over time in value relative to other products.

237

238 Law enforcement in 2014

239 One-day surveys at potential export locations in the capital, Libreville (seaport,

240 airport, train station and bus station) were carried out in collaboration with law

241 enforcement agencies and concentrated on current practices used for interception

242 of illegal trade and collation of annual seizures, rather than numbers seized during

243 the survey days. Nationwide data on seizures of pangolins or pangolin products were

244 obtained from all relevant government agencies (Ministry of Forests and Protection

245 of the Environment (Ministère des Forêts de de la Protection de la Nature), the

246 Convention on International Trade in Endangered Species (CITES) Management 
Authority for Gabon, National Police Force (Gendarmerie Nationale), the Border

Police (Police des Aires et Frontières), Customs (Douanes Nationales) and National

249 Parks Agency (Agence Nationale des Parcs Nationaux; ANPN) for assessment of law 250 enforcement efforts (2012-2015) and potential export routes.

\section{Results}

253 Hunters and traders did not reliably differentiate between the two Phataginus 254 species of pangolin in either the 2014 surveys or the 2002-2003 village studies, thus 255 data are given collectively for 'arboreal pangolins'.

\section{Village hunting and 'forestgate' trade in 2014}

258 Of village hunters who gave information on sales (90/103), all hunters reported 259 catching an arboreal pangolin 'commonly' and $89 \%$ of hunters reported sale of an 260 arboreal pangolin in the past three months.

261 The average price per kg for all bushmeat carcasses recorded as sold at the roadside

262 in villages was not significantly different between the two provinces. Mean 2014

263 roadside price for all bushmeat was $1008 \pm 400$ FCFA (US\$1.81 \pm 0.72 ) per kg for 514

264 records from hunter sales. Figure 3 shows mean price per kg for all sales reported by 265 hunters in 2014. Both types of pangolin sold at a higher price per kg than the mean 266 price of all bushmeat: whole arboreal pangolins (estimated at $1.8 \mathrm{~kg}$ from a sample of 26793 hunted animals weighed in Gabon; Coad, 2007, Hymas, unpublished data) were 268 sold at a mean roadside price of $2,447 \pm 930$ FCFA (US\$4.40 \pm 1.67 ), equivalent to $2691,359 \pm 517$ FCFA (US\$2.45 \pm 0.93 ) per $\mathrm{kg}$ ( $\mathrm{n}=65$ sales observed during field study). 270 Giant pangolins (estimated at $28.75 \mathrm{~kg}$ ) sold at the roadside at a mean price of 
272 per kg $(n=25)$.

273

274 Expressed demand for pangolins in rural areas in 2014

275 The majority (70\%) of hunters reported only selling their meat opportunistically. Of

276 the $30 \%$ of hunters that took orders for meat before hunting, $34 \%$ of their customer

277 base (by number of clients) were Asian immigrants, although hunters did not know

278 the particular nationality of individual clients. All hunters that took orders for meat

279 before hunting were from the Ogooué Ivindo. Meat orders placed by Asian clients

280 were heavily biased to pangolins (Figure 2). Hunters and village chiefs reported no

281 knowledge of hunting in the forest by immigrant workers themselves, in either

282 province.

283

284 Change in rank position of pangolin species within the traditional bushmeat trade

285 Sixteen species were recorded in the markets in 2014. The top five species, or

286 species groups, sold by total number of carcasses in all markets were, in rank order;

287 blue duiker (26.1\% carcasses), brush-tailed porcupine (20.3\%), red duikers (18.8\%),

288 red river hog (9.4\%) and guenons (7.2\%). Arboreal pangolins were the sixth most-

289 traded species, forming $4.3 \%$ of all carcasses and giant pangolins were the seventh

290 most-traded species, forming $3.6 \%$ of all carcasses sold.

291 Change over time and space in market value

292 The price of any bushmeat at the forestgate in Ogooué Ivindo had risen from a mean

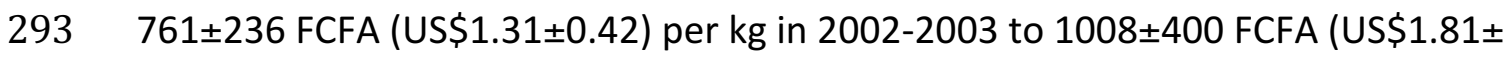

294 0.72) in 2014; an increase of 32\% of the 2002 price. Pangolins were traded at above 
average per kg prices in both 2002 and 2014, but the relative price increase was far

296 greater for giant pangolins, which sold in 2014 for $52 \%$ more than their 2002 price,

297 whilst the price of arboreal pangolins had only risen by $9 \%$ on the 2002 forestgate

298 value.

299 Using prices of whole animals of the most common and comparable species; blue

300 duikers and brush-tailed porcupines account for around $50 \%$ of all sales, Makokou

301 town prices for whole, fresh animals had risen from $3631 \pm 1177$ FCFA (US\$6.53 \pm 2.12 )

302 to $5453 \pm 1297$ FCFA (US\$9.81 \pm 2.33 ) per carcass, and Libreville prices had risen from

$3038455 \pm 1716$ FCFA (US\$15.22 \pm 3.09 ) to $15700 \pm 4461$ FCFA (US\$28.26 \pm 8.03 ), relative

304 rises of $50 \%$ and $87 \%$ on 2002 prices. During the same period, the average price of

305 giant and arboreal pangolins in Libreville rose by $212 \%$ and $74 \%$ respectively (Figure

$3064)$.

307

308 Law enforcement

309 During 2014, government wildlife law enforcement teams with sniffer dogs carried

310 out 209 control missions on potential export routes at the Libreville seaport and

311 airport, the N1 major road artery into and out of Libreville and the train station.

312 Daily controls without dogs also operated at five roadblocks on major road arteries

313 across the country. Standard customs controls not specialized to wildlife issues also

314 operated on all flights departing the international airport and ships departing the

315 seaport. Illegally held pangolins were located and seized on only four occasions:

316 three on the $\mathrm{N} 1$ road and one at the train station, recovering in total twelve arboreal

317 pangolins, equivalent to approximately $21 \mathrm{~kg}$ total weight. In 2015 (January-June)

318 teams working at the same locations made one seizure of scales in the town of 
Oyem. These scales were reportedly destined for a Chinese buyer in Equatorial

320 Guinea who regularly placed orders with Gabonese hunters and were associated

321 with a seizure of ivory. No seizures of pangolins or products were made at the

322 international transport hubs.

323

324 Discussion

325 We set out to describe the current position of pangolins within the traditional

326 subsistence trade chain, to evaluate the extent of change over the past decade in the

327 trade from forestgate to city, and to assess the extent to which rural hunting

328 communities may be a source of pangolins for international trade, and how and

329 where illegal trade maybe emerging. We have found that

330 1. Frequency of sale of pangolins, particularly giant pangolins, may be increasing

331 within the traditional bushmeat market chains, but that these increases are (as

332 yet) small and may not reflect an increase in hunter offtakes for arboreal

333 pangolins. In 2000-2006, although giant pangolins were recorded in trade, the

334 species did not appear in the eighteen most commonly-traded species from a

335 comprehensive survey across Gabon (Abernethy \& Ndong Obiang, 2010). Yet in

336 our 2014 study they are the seventh most-traded species. It is likely that their

337 sale frequency has risen overall in our study areas and possibly nationwide.

338 2. All pangolins have increased in value over time, relative to other species within

339 the existing bushmeat trade structure. Relative value increases are most

340 extreme in most urban areas and smaller in rural areas. This is consistent with

341 absence of a high-value trade developing from within the traditional market

342 trade and otherwise primarily involving village hunters. 
343 3. Specific demand for pangolins expressed to village hunters is high in certain 344 areas relative to expressed demand for other species, and particularly for 345 consumption by the immigrant Asian population.

346 4. Giant pangolins have become relatively more valuable than arboreal pangolins, 347 which is in line with their much higher weight of scales, if scale price is a 348 determinant of value.

349 5. Despite an intensification of law enforcement effort to detect pangolin trafficking, no movement through public international or domestic transport hubs has been detected. Instead, a very small number of informal trade routes have been found across forest borders where no enforcement is routinely made. It is probable that clients within established illegal trade chains for ivory may also be expressing a demand for pangolin scales.

355 There is little evidence from our surveys of village hunters that they are engaging at 356 present in hunting pangolins for more commercial purposes, nor in greater numbers, 357 than in 2002-3. The top five species reported by hunters in this study as most 358 frequently caught are very similar to those found by hunter studies a decade ago 359 (the top five species in 2014 village catches were also found in the top eight species 360 in all 2002-2006 studies: Okouyi Okouyi, 2006, Coad 2007, van Vliet, 2008). These 361 results suggest that this hunting is still primarily oriented towards subsistence, rather 362 than newer commercial possibilities associated with intercontinental trafficking. 363 Although village hunters are experiencing high local demand for pangolins from 364 Asian immigrant workers, and are providing supply, it would be possible to achieve 365 more pangolin sales in 2014 than in 2002-3 without initially increasing offtakes. Coad 366 (2007) found village hunters traded only $10 \%$ of the pangolins they hunted, 
consuming the rest at home. Thus, there is significant potential for increased trade

to be recorded without necessarily increased offtakes, simply by hunters deciding to

369 sell, rather than consume, their catch.

370 Arboreal pangolins were only the tenth and twelfth most traded species in markets

371 nationally between 2000-2006 (Abernethy and Obiang Ndong, 2010), yet in this

372 study were the sixth most-traded species (by number of carcasses sold). The large

373 difference in sample size and period means that this result must be interpreted with

374 caution, however it supports the conclusion that arboreal pangolins may be traded

375 more often in 2014 than they were in 2002-2003, whether or not offtakes from the

376 forest are higher. Sustained demand and high value will be almost certain to create

377 increased offtakes from the village hunting grounds over time.

378 The 2015 seizure of $2 \mathrm{~kg}$ of scales in Oyem was the first domestic interception of

379 scale trade, despite considerable efforts since 2012 dedicated to controlling major

380 transport hubs and focusing search efforts on pangolins and their derivatives. The

381 trader intercepted was also dealing in ivory and reported having regularly supplied

382 the Chinese client involved for the past two years, exporting scales informally across

383 a forest border to a specific recipient, rather than using established bushmeat

384 traders within the country to offer the product for general sale alongside meat. In

3852016 a second ivory trader was also intercepted in the Minkébé region of Gabon,

386 with 2 sacks of pangolin scales associated with a seizure of raw ivory (ANPN, 2016).

387 Although these are small pieces of evidence, combined with the lack of seizures of

388 pangolins in major domestic transport hubs and the traditional bushmeat trade

389 network, even these anecdotes provide some insight into the possible mechanisms

390 of new illegal trade emergence. 
391 We conclude that the beginnings of higher value trade chains are possible and

392 indeed probable for each species of pangolin. both within and from Gabon, and that

393 pathways for increasing the trade of pangolins hunted in villages are already evident,

394 even if this trade is not yet fully realised. The value of giant pangolins in domestic

395 trade has increased greatly in urban markets, despite the species' fully protected

396 status, which is an indicator that pressure on this species may be higher and

397 expressed more rapidly than demand for arboreal pangolins. Whilst we demonstrate

398 that illegal trade networks for pangolins may evolve outside of the traditional

399 bushmeat market structure and be 'invisible' to traditional meat market surveys and

400 controls, evolution of pangolin trade both within and outside the traditional

401 bushmeat supply is of course possible.

402 If the international pangolin trade is not sourcing animals from the traditional

403 bushmeat markets, then it may be difficult to detect a parallel trade structure using

404 the current conservation strategies. We see an immediate need for pro-active

405 monitoring of the hunting and trade of pangolins in villages and a diversification of

406 pangolin-focused law enforcement activities. Such actions will require innovation on

407 the part of government agencies and NGOs supporting such efforts, an increase of

408 resources dedicated to combatting the illegal wildlife trade in and from Gabon, and

409 strengthening of multiple international collaborations. However, we feel it is useful

410 to all future partners to set out a road map for conservation action for pangolins in

411 Gabon from this point forwards.

412 Specific recommendations are:

413 1. Improved enforcement and interception efforts in less frequently-used

414 domestic trade and potential export routes, to complement current efforts 
on larger transport hubs, including paying particular attention to detecting and recording concurrent seizures of pangolins and ivory.

2. Improved traceability of seizures involving pangolins and their derivatives, through

a. improved national capacity for tracing origins of domestic illegal trade (giant pangolins) to source, for example by monitoring transport links;

b. improved collaboration and participation of the Gabonese State agencies in international enforcement tools for all pangolins (i.e. CITES permits and trade monitoring; Heinrich et al., 2016, Challender \& Waterman, 2017); and

c. mapping of genotypic variation of wild Gabonese pangolin populations to enable differentiation of origin within the country, as well as across the species' global range (i.e. Gaubert et al., 2016).

3. to ensure robust monitoring of subsistence hunter pressure by working with local hunters and villages in order to:

a. detect changes in offtake, including to better understand the sustainability of current harvests (Coad et al., 2013; Ingram et al; 2017); and

b. to enable early reactivity to increased commercial trade and/or trafficking.

4. to support and encourage robust scientific research on wild pangolin populations in Gabon, with a particular focus on determining the status of populations in quantitative terms and temporal trends, such that baselines can be established to properly underpin national conservation measures and 
441

442

443 
Abernethy, K.A. \& Ndong Obiang, A.M. (2010). Bushmeat in Gabon. Libreville, Gabon: Technical Report, Ministère des Eaux et Forets. doi:

\subsection{0/RG.2.2.28730.18881}

Abernethy, K.A., Maisels, F. \& White, L.J.T. (2016). Environmental Issues in Central Africa. Annual Review of Environment and Resources, 41, 1-33. doi:10.1146/annurev-environ-110615-085415

ANPN (2016). Rapport des saisies d'ivoire 2016. Internal report of the Gabon National Parks Agency Technical Directorate.

Baker, F. (2014). Assessing The Asian Industry Link In The Intercontinental Trade Of African Pangolins, Gabon (Masters Thesis). Imperial College London, UK.

Challender, D.W.S. (2011). Asian pangolins: increasing affluence driving hunting pressure. TRAFFIC Bulletin, 23 (1), 92-93.

Challender, D.W.S., Baillie, J.E.M., Waterman, C., Pietersen, D., Nash, H., Wicker, L., Parker, K., Thomson, P., Nguyen, T.V., Hywood, L. \& Shephard, C.R. (2016). On Scaling Up Pangolin Conservation. TRAFFIC Bulletin, 28(1), 19-21.

Challender, D. W. S., Harrop, S. R. \& Macmillan, D. C. (2015). Understanding markets to conserve trade-threatened species in CITES. Biological Conservation, 187, 249-259. doi:10.1016/j.biocon.2015.04.015

Challender, D. \& Hywood, L. (2012). African Pangolins under increased pressure from poaching and intercontinental trade. TRAFFIC Bulletin, 24(2), 53-55.

Challender, D.W.S. \& Waterman, C. (2017). Implementation of CITES Decisions 17.239 b) and 17.240 on Pangolins (Manis spp.). CITES SC69 Doc. 57 Annex 1. CITES, Geneva, Switzerland. Available at https://cites.org/sites/default/files/eng/com/sc/69/E-SC69-57-A.pdf

Coad, L. (2007). Hunter behaviour and rural village subsistence hunting in Gabon. $\mathrm{PhD}$ thesis, Imperial College, London, England.

Coad, L., Schleicher, J., Milner-Gulland, E.J., Marthews, T.R., Starkey, M., Manica, A., Balmford, A., Mbombe, W., Diop Bineni, T.R. \& Abernethy, K.A. (2013). Social and Ecological Change over a Decade in a Village Hunting System, Central Gabon. Conservation Biology, 27, 270-280. doi:10.1111/cobi.12012

Dirzo, R., Young, H. S., Galetti, M., Ceballos, G., Isaac, N. J. B. \& Collen, B. (2014). Defaunation in the Anthropocene. Science, 345, 401-405. doi:10.1126/science.1251817

Foerster, S., Wilkie, D. S., Morelli, G. A., Demmer, J., Starkey, M., Telfer, P. \& Steil, M. (2011). Human livelihoods and protected areas in Gabon: a cross-sectional comparison of welfare and consumption patterns. Oryx, 45(3), 347-356. doi:10.1017/S0030605310001791

Gaubert, P., Njiokou, F., Ngua, G., Afiademanyo, K., Dufour, S., Malekani, J., Gonedele Bi, S., Tougard,C., Olayemi,A., Danquah,E., Djagoun, C.A.M.S., Kalemep., Mololo, C.N., Stanley,W., Luo, S-J. \& Antunes, A. (2016). Phylogeography of the heavily poached African common pangolin (Pholidota, Manis tricuspis) reveals six cryptic lineages as traceable signatures of Pleistocene diversification. Molecular Ecology, 25(23), 5975-5993. doi:10.1111/mec.13886 
Heinrich, S., Wittmann, T. A., Prowse, T. A. A., Ross, J. V., Delean, S., Shepherd, C. R. \& Cassey, P. (2016). Where did all the pangolins go? International CITES trade in pangolin species. Global Ecology and Conservation, 8, 241-253. doi:10.1016/j.gecco.2016.09.007

Ingram, D.J., Coad, L.M., Abernethy, K.A., Maisels, F., Stokes, E., Bobo Kadiri, S., Breuer, T, Gandiwa, E., Ghiurghi, A, Greengrass, E., Holmern, T, Kamgaing, T, Ndong-Obiang, A-M, Poulsen, J, Schleicher, J., Nielsen, M., Solly, H., Vath, C.L., Waltert, M, Whitham, C, Wilie, D.S. \& Scharlemann, J.S. (2017). Assessing Africa-Wide Pangolin Exploitation by Scaling Local Data. Conservation Letters doi. 10.1111/conl.12389

IUCN (2014). The Red List of Threatened Species Version 2014.3. IUCN.

Kasane Statement on the Illegal Wildlife Trade. (2015, March 25). Retrieved from https://www.gov.uk/government/publications/illegal-wildlife-trade-kasanestatement.

Kingdon, J. \& Hoffman, M. (2013). The Pangolins. In The Mammals Of Africa (Vol. Volume 1). London UK: Bloomsbury.

LAGA (2017). Monthly Action Report, January 2017. Retrieved from http://www.lagaenforcement.org/MonthlyAction/MonthlyAction2017/tabid/274/language/e n-US/Default.aspx

London Declaration on the Illegal Wildlife Trade (2014). Retrieved from https://www.gov.uk/government/publications/declaration-londonconference-on-the-illegal-wildlife-trade

Mambeya, M. M. (2015). Socio-economic survey of hunters in the provinces of Ogooue Ivindo and Nyanga (Gabon). (Master of Science thesis). Northeast Agricultural University, Harbin, China.

Newman, C., Macdonald, D. W. \& Zhou, Y. (2014). Pangolin: illegal medicine trade threatens these scaly mammals with extinction. The Conversation, $(7$ November 2014). Retrieved from http://theconversation.com/pangolinillegal-medicine-trade-threatens-these-scaly-mammals-with-extinction-33817

Nijman, V., Zhang, M. X. \& Shepherd, C. R. (2016). Pangolin trade in the Mong La wildlife market and the role of Myanmar in the smuggling of pangolins into China. Global Ecology and Conservation, 5, 118-126. doi:10.1016/j.gecco.2015.12.003

Okouyi Okouyi, V. J. J. (2006). Savoirs locaux et outils modernes cynégétiques : développement de la filière commerciale de viande de brousse à Makokou (Gabon) (PhD Thesis). Université d'Orléans, Orléans, France.

Oxford Business Group (2015). The Report - Gabon 2014. Oxford, UK. Retrieved from http://www.oxfordbusinessgroup.com/gabon-2014

Putzel, L., Assembe-Mvondo, S., Bilogho Bi-Ndong, L., Banioguila, R.P., Cerutti, P., Tieguhong, J.C., Djeukam, R., Kabuyaya, N., Lescuyer, G. \& Mala, W. (2011). Chinese trade and investment and the forests of the Congo Basin: synthesis of scoping studies in Cameroon, Democratic Republic of Congo and Gabon. Bogor Indonesia: CIFOR.

Republique Gabonaise 1987. Decree 189/PR/MEFCR. Retrieved from http://www.observatoire- 
comifac.net/pages/monitoring_system/national_indicators.php?country=GA $B \&$ step $=2$ Lindsey, P.A., Macdonald, D.W., Machovina, B., Newsome, T.M., Peres, C.A., Wallach, A.D., Wolf, C. \& Young, H. (2016). Bushmeat hunting and extinction risk to the world's mammals. Royal Society Open Science, 3(10), 160498. doi:10.1098/rsos.160498

Starkey, M. (2004). Commerce and subsistence: the hunting, sale and consumption of bushmeat in Gabon. (PhD Thesis) Cambridge University, Fitzwilliam College, Cambridge, England.

Van Vliet, N. (2008). Variabilite spatiale et temporelle au sein du systeme chasseuranimal-territoire de chasse villageois (PhD Thesis). Universite Toulouse le Mirail, Toulouse, France.

550

Wang, J.-Y. \& Bio-Tchané, A. (2008). Africa's Burgeoning Ties with China. Finance and Development, 45(1), 44-47. 


\section{Tables.}

552 Table 1. Hunter sale 'forestgate' price changes over 12 years from 2002-2014 in the

553 Ogooué Ivindo villages. Data from the 2002-2003 sample were limited to records

554 from May-September for comparison to the 2014 sampling period. The lines for

555 pangolin records are shaded.

\section{6}

\begin{tabular}{|c|c|c|c|c|c|c|c|c|}
\hline \multirow[b]{2}{*}{ Species group } & \multirow[b]{2}{*}{$\begin{array}{c}\text { Body } \\
\text { Weight } \\
(\mathrm{kg})\end{array}$} & \multicolumn{3}{|c|}{2002} & \multicolumn{3}{|c|}{2014} & \multirow[b]{2}{*}{$\begin{array}{c}\text { price } \\
\text { increase } \\
(\% \text { 2002) }\end{array}$} \\
\hline & & $\begin{array}{c}\text { Price/kg FCFA } \\
\text { (SD) }\end{array}$ & $\begin{array}{r}\text { Equivalent } \\
\text { Price/kg US\$ } \\
(S D)\end{array}$ & $\mathrm{N}$ & $\begin{array}{c}\text { Price/kg } \\
\text { FCFA } \\
\text { (SD) } \\
\end{array}$ & $\begin{array}{c}\text { Price/kg } \\
\text { US\$ } \\
\text { (SD) }\end{array}$ & $\mathrm{N}$ & \\
\hline Red duiker & 16.2 & $661(126)$ & $1.19(0.23)$ & 347 & $\begin{array}{r}715 \\
(239) \\
\end{array}$ & $1.29(0.43)$ & 72 & 8 \\
\hline $\begin{array}{l}\text { Arboreal } \\
\text { pangolin }\end{array}$ & 1.8 & 1,252 (209) & $2.25(0.38)$ & 16 & $\begin{array}{r}1,359 \\
(334) \\
\end{array}$ & $2.45(0.60)$ & 57 & 9 \\
\hline Blue duiker & 4.2 & 744 (182) & $1.34(0.33)$ & 34 & $\begin{array}{r}879 \\
(312) \\
\end{array}$ & $1.58(0.56)$ & 56 & 18 \\
\hline $\begin{array}{l}\text { Brush tailed } \\
\text { porcupine }\end{array}$ & 3.4 & 1,013 (175) & $1.82(0.31)$ & 63 & $\begin{array}{r}1,240 \\
(257) \\
\end{array}$ & $2.23(0.46)$ & 58 & 22 \\
\hline All species & & $761(236)$ & $1.37(0.42)$ & 966 & $\begin{array}{r}1,008 \\
(400) \\
\end{array}$ & $1.81(0.72)$ & 515 & 32 \\
\hline Red river hog & 55.0 & 569 (97) & $1.02(0.17)$ & 73 & $\begin{array}{r}765 \\
(301) \\
\end{array}$ & $1.38(0.54)$ & 91 & 34 \\
\hline Guenon & 4.0 & $676(204)$ & $1.22(0.37)$ & 36 & $\begin{array}{r}945 \\
(619) \\
\end{array}$ & $1.70(1.11)$ & 25 & 40 \\
\hline Giant pangolin & 28.8 & 874 (598) & $1.57(1.08)$ & 53 & $\begin{array}{r}1,325 \\
(517) \\
\end{array}$ & $2.38(0.93)$ & 66 & 52 \\
\hline
\end{tabular}

557 
559 Figure 1. The study sites in Gabon. Libreville is the national capital city and Makokou

560 and Tchibanga are provincial capitals. Hunters were interviewed in the villages

561 (shown as black dots) supplying these two provincial town markets. Villages in

562 Gabon are generally situated along the road network, in similar densities to those

563 shown around the two provincial towns studied.

564

565 Figure 2. Requests received from locally based Asian industrial workers between

566 March and May 2014 by hunters from surveyed Ogooué-Ivindo villages, for supply of 567 particular species ( $\mathrm{N}=34$ specific requests recorded).

568

569 Figure 3. Mean price per kg FCFA ( $\$ 1$ USD = 555 FCFA) for species sold by hunters at 570 the forestgate in 2014 ( $N$ sales). Error bars represent the SE of prices. Bodyweights

571 were taken from empirical data for weighed carcasses in Gabon (Coad, 2007 \&

572 Abernethy \& Ndong Obiang, 2010). At equal meat value, by bodyweight, giant

573 pangolins would be expected to sell for a similar price to red duikers and red river

574 hog, approximately half their actual sale price. The bar for the mean of all species is

575 shown in white and bars for pangolin species in brown.

576

577 Figure 4. Percentage (of earlier price) rise in mean price between 2002-2003 and

5782014 for whole animal sales of a) most commonly sold taxa under $5 \mathrm{~kg}$ (palm civet,

579 blue duiker, brush-tailed porcupine, arboreal pangolins and guenons) b) arboreal

580 pangolins c) Giant pangolins recorded from forestgate villages, Makokou town and in

581 Libreville's largest market (Mont Bouët). 